\title{
Effect of systemic steroids on post-tonsillectomy bleeding and reinterventions: systematic review and meta-analysis of randomised controlled trials
}

\author{
(C) $(1) \Theta$ OPEN ACCESS
}

\begin{abstract}
Jennifer Plante fellow ${ }^{1}$, Alexis F Turgeon assistant professor ${ }^{12}$, Ryan Zarychanski assistant professor $^{34}$, François Lauzier assistant professor ${ }^{125}$, Louise Vigneault lecturer ${ }^{1}$, Lynne Moore assistant professor ${ }^{26}$, Amélie Boutin research assistant ${ }^{2}$, Dean A Fergusson associate professor ${ }^{7}$

'Department of Anesthesiology, Division of Critical Care Medicine, Université Laval, Centre Hospitalier Affilié Universitaire de Québec ( $\mathrm{CH} A)$, Enfant-Jésus Hospital, Québec City, QC, Canada, G1J 1Z4; ${ }^{2} \mathrm{CH} A$ Research Center (Enfant-Jésus Hospital), Trauma-Emergency-Critical Care Medicine Unit, Université Laval; ${ }^{3}$ Department of Hematology and Medical Oncology, CancerCare Manitoba, Winnipeg, MB, Canada; ${ }^{4}$ Departments of Internal Medicine and of Community Health Sciences, University of Manitoba, Winnipeg; ${ }^{5}$ Department de Medicine, Université Laval; ${ }^{6}$ Department of Social and Preventive Medicine, Université Laval; ${ }^{7}$ Clinical Epidemiology Program, Ottawa Hospital Research Institute, Ottawa, ON, Canada
\end{abstract}

\begin{abstract}
Objective To evaluate the risk of postoperative bleeding and reintervention with the use of systemic steroids in patients undergoing tonsillectomy.

Design Systematic review and meta-analysis of randomised controlled trials.

Data sources Medline, Embase, Cochrane Library, Scopus, Web of Science, Intute, Biosis, OpenSIGLE, National Technical Information Service, and Google Scholar were searched. References from reviews identified in the search and from included studies were scanned.

Review methods Randomised controlled trials comparing the administration of systemic steroids during tonsillectomy with any other comparator were eligible. Primary outcome was postoperative bleeding. Secondary outcomes were the rate of admission for a bleeding episode, reintervention for a bleeding episode, blood transfusion, and mortality.

Results Of 1387 citations identified, 29 randomised controlled trials $(n=2674)$ met all eligibility criteria. Seven studies presented a low risk of bias, but none was specifically designed to systematically identify postoperative bleeding. Administration of systemic steroids did not significantly increase the incidence of post-tonsillectomy bleeding (29 studies, $n=2674$ patients, odds ratio 0.96 (95\% confidence interval 0.66 to 1.40$), I^{2}=0 \%$ ). We observed a significant increase in the incidence of operative reinterventions for bleeding episodes in patients who received systemic steroids $(12, n=1178,2.27$ ( 1.03 to 4.99$), \mathrm{I}^{2}=0 \%$ ). No deaths were reported. Sensitivity analyses were consistent with the findings.
\end{abstract}

Conclusions Although systemic steroids do not appear to increase bleeding events after tonsillectomy, their use is associated with a raised incidence of operative reinterventions for bleeding episodes, which may be related to increased severity of bleeding events. Systemic steroids should be used with caution, and the risks and benefits weighed, for the prevention of postoperative nausea and vomiting after tonsillectomy before further research is performed to clarify their condition of use.

\section{Introduction}

Tonsillectomy with or without adenoidectomy is one of the most commonly performed ear, nose, and throat surgeries worldwide. ${ }^{12}$ After this intervention, many patients have nausea, vomiting, and pain. ${ }^{34}$ Without prophylaxis, the reported incidence of postoperative vomiting in children undergoing tonsillectomy ranges from $40 \%$ to $73 \% .^{5-8}$ Systemic steroids have been shown to be as efficient as $5-\mathrm{HT}_{3}$ antagonists and droperidol in reducing postoperative nausea and vomiting. ${ }^{8}$ Their use is increasing and currently recommended in recent guidelines of the American Academy of Otolaryngology-Head and Neck Surgery Foundation for tonsillectomy in children. ${ }^{9}{ }^{10}$ Furthermore, some studies suggest that steroids could be associated with an earlier return to a regular diet after tonsillectomy. ${ }^{211}$

A recent randomised controlled trial comparing different doses of dexamethasone for preventing postoperative nausea and vomiting after tonsillectomy showed an increased incidence of 
postoperative bleeding and reoperation due to bleeding in the steroid group. ${ }^{12}$ Previous observational studies have also reported this association. ${ }^{13}{ }^{14}$ A recent meta-analysis on dexamethasone and tonsillectomy bleeding found no increased risk of postoperative bleeding with the use of steroids. ${ }^{15}$ However, this review was not exhaustive and did not evaluate clinically significant outcomes such as operative reinterventions.

Considering the frequent use and potential harm of systemic steroids to prevent postoperative nausea and vomiting after tonsillectomy, and the existence of effective alternatives such as $5-\mathrm{HT}_{3}$ antagonists, ${ }^{10}$ we conducted a systematic review of randomised controlled trials to evaluate the risk of postoperative bleeding and of operative reinterventions after systemic steroids use in patients undergoing tonsillectomy.

\section{Methods}

\section{Design and search strategy}

We conducted a systematic review and meta-analysis of randomised controlled trials. A search strategy was developed for Medline (OVID, 1950-March 2011), Embase (OVID, 1947-March 2011), and the Cochrane Central Register of Controlled Trials (up to March 2011) (web appendix). We identified randomised controlled trials by incorporating validated filters for Medline ${ }^{16}$ and Embase.$^{17}$ We also did a similar search of Scopus, the Web of Science, and Intute databases, as well as OpenSIGLE, Google Scholar, and the National Technical Information Service databases for the grey literature. Relevant abstracts and conference proceedings were identified using the Biosis database. References of pertinent reviews identified in the search were scanned to identify potentially relevant trials. Two reviewers (JP, LV) independently screened all studies for eligibility by titles and abstracts, and by full text publications if needed. A third reviewer (AFT) was consulted in instances when consensus could not be reached between the two reviewers. At the end of this selection process, Google Scholar was used to identify authors that cited any of the included studies. Additional studies identified by this method were then considered for eligibility.

\section{Study eligibility}

All randomised controlled trials of tonsillectomy (any indications) that compared the administration of any systemic steroids to any comparator (other intervention, placebo, or no intervention) were included, provided that bleeding or the absence of bleeding episodes (of any severity) were also reported or could be obtained from authors. We excluded studies including patients with bleeding disorders, patients on chronic steroid therapy, or patients in whom steroids were locally injected or sprayed on the tonsillar bed. Eligibility was not restricted by language, type of publication (for example, abstracts or full publications), or patients' age.

The primary outcome was the incidence of postoperative bleeding from the tonsillar fossa (any type of bleeding and of any severity). The secondary outcomes were the incidence of admission for bleeding episodes, operative reinterventions for bleeding episodes, red blood cells transfusion, and mortality. We defined an operative reintervention for a bleeding episode as any surgical procedure performed in the operating room or in the emergency department to stop bleeding from the surgical site. Patients requiring a reintervention in the operating room were considered being admitted to hospital after the procedure, and were included in the meta-analysis of admissions for bleeding episodes.

\section{Data abstraction}

We developed a data abstraction form to standardise the data collection process, which was pilot tested on a landmark publication. ${ }^{12}$ For comparison purposes, all steroid doses were converted in dexamethasone equivalents. We converted fixed doses to $\mathrm{mg} / \mathrm{kg}$ using the mean weight, when the data were provided. If weight was not provided, we used a standard weight of $60 \mathrm{~kg}$ for women and $70 \mathrm{~kg}$ for men in adults, and weight charts for children to estimate whether the mean dose was lower or greater than $0.5 \mathrm{mg} / \mathrm{kg}$. Bleeding events that occurred on postoperative day zero, or within the first 24 hours, were considered as primary bleeding episodes. Episodes beyond that period of time were defined as secondary bleeding episodes. We contacted the corresponding authors of included studies if data were missing for bleeding episodes, admission, reintervention, red blood cells transfusion, or mortality, or if the methods required clarification. Two reviewers (JP, LV) performed the data collection process independently, and a third reviewer (AFT) resolved any discrepancies. A translator was consulted for studies published in languages other than English or French.

\section{Risk of bias assessment}

The risk of bias was assessed independently by two reviewers (JP, LV) using the Cochrane Collaboration's risk of bias tool. ${ }^{16}$ Since the objective of the current review was to identify bleeding complications occurring in the acute and subacute perioperative period, studies with considerable numbers of patients lost to follow-up, as well as those with a short follow-up period $(<24$ h) were considered to have an increased risk of bias because of their potential for missed bleeding events. ${ }^{16}$ For this reason, we assigned an "unclear" overall risk of bias to studies with a proportion of lost to follow-up greater than $10 \%$ (incomplete outcome data).

\section{Data synthesis}

Data were analysed using Cochrane Review Manager version 5.0 (Cochrane Collaboration) and summarised using Peto fixed effects models, appropriate for meta-analysis of rare events. ${ }^{18}$ We applied a continuity correction of 0.5 to studies reporting no event in both groups. All data were dichotomous, and associations were presented using odds ratio with $95 \%$ confidence intervals. An odds ratio greater than 1 implies greater risk in the steroid group, and an odds ratio less than 1 implies greater risk in the control group. We assessed the presence of heterogeneity using the $\mathrm{I}^{2}$ statistic, which estimates the percentage of variation between study results that is due to heterogeneity rather than sampling error. ${ }^{19} \mathrm{We}$ did sensitivity analyses, based on clinical (adults $v$ children, cold or combined $v$ hot dissection, high $[>0.5 \mathrm{mg} / \mathrm{kg}] v$ low $[\leq 0.5 \mathrm{mg} / \mathrm{kg}]$ dose steroids, non-steroidal anti-inflammatory drug administration, type of comparator, and timing of bleeding) and methodological (risk of bias, blinding, sample size, and short $[\leq 24 \mathrm{~h}] v$ long [ $>24 \mathrm{~h}$ ] follow-up) characteristics, to understand potential sources of heterogeneity and to evaluate the robustness of the results. Potential publication bias was assessed using funnel plot analyses. $^{20}$

\section{Quality of evidence}

We graded the quality of evidence for the three main outcomes using the Grading of Recommendations Assessment, Development and Evaluation (GRADE) approach ${ }^{21}$ with GRADEpro software (version 3.2 for Windows. Jan Brozek, Andrew Oxman, Holger Schünemann, 2008). 


\section{Results}

\section{Search results}

We retrieved a total of 1387 citations (fig $1 \Downarrow$ ). Fifty one studies were considered potentially eligible. Of these studies, 16 were excluded because they did not report bleeding episodes nor admission or reintervention, and this information could not be obtained despite attempts to contact the authors. The remaining excluded publications did not meet all inclusion criteria. ${ }^{22-27} \mathrm{We}$ included 29 studies in this systematic review, ${ }^{128-55}$ representing 2674 patients (table $1 \Downarrow$ ).

\section{Study characteristics}

Of the included studies, 24 were published in English, and one each in Turkish, ${ }^{34}$ Korean, ${ }^{39}$ Spanish,${ }^{54}$ Chinese, ${ }^{29}$ and Hebrew. ${ }^{38}$ Ten studies were conducted in North America, ${ }^{30-33} 354047$ 53-55 12 in Asia, ${ }^{28} 293437-3941454649-51$ four in Europe, ${ }^{12} 424352$ two in Australia, ${ }^{3648}$ and one in Africa. ${ }^{44}$ All studies were presented as full publications. In two studies, dexamethasone was provided by pharmaceutical companies, ${ }^{12}{ }^{32}$ and one of these studies specified that the funding organisation had no role in the design or conduct of the study. ${ }^{12}$

Nineteen studies were performed in children, six in adults only, and four included both children and adults. Twenty four studies compared the effects of systemic steroids with placebo $^{12} 28-353740414346-48505153-55$ or no intervention (neither a placebo nor any intervention in the control group). ${ }^{38}{ }^{39} 45 \mathrm{Six}$ studies compared systemic steroids with other treatments (tropisetron, ondansetron, droperidol, piroxicam, bilateral glossopharyngeal nerve block with bupivacaine, or paracetamol).

Dexamethasone was used in 28 studies, while prednisolone was administered in the remaining study.$^{48}$ In 18 studies, the dexamethasone dose was calculated according to the patient's weight $(\mathrm{mg} / \mathrm{kg})$ and varied from $0.05 \mathrm{mg} / \mathrm{kg}{ }^{12}$ to $1.0 \mathrm{mg} / \mathrm{kg}$. In the remaining studies, the steroid dose was fixed ${ }^{29} 31404243505255$; based on the patient's body surface $\left(\mathrm{mg} / \mathrm{m}^{2}\right)^{32}$; or either fixed or based on weight $(\mathrm{mg} / \mathrm{kg})$, according to patient's age. ${ }^{48} 49$ Systemic steroids were administrated as a single dose, or repeated doses over a specific period of time: $16 \mathrm{~h},{ }^{54}$ three days, ${ }^{40}$ four days, ${ }^{29}$ seven days, ${ }^{48}$ or eight days. ${ }^{52}$ In these studies, the total dose was taken into account.

In most studies, the main outcomes were the effect of steroids on pain, ${ }^{12} 28-33$ 35 $37-454748$ 50-55 nausea and vomiting, ${ }^{12} 283033-394143$ 45-53 and oral intake $122830323537-39414345-4850515355$ after tonsillectomy. Other main outcome measures of included studies were the effect of steroids on oedema, fever, trismus, halitosis, and level of activity.

Twenty six studies reported data for post-tonsillectomy bleeding. Through private communications with authors, we obtained details pertaining to the severity of and to interventions related to the bleeding episodes for three of these studies, ${ }^{40}{ }^{42}$ and obtained unpublished data on bleeding episodes for three additional studies. ${ }^{43449}$ Eight studies reported no postoperative bleeding episodes or mentioned uneventful

surgeries. ${ }^{29} 37434448495154$ Among studies reporting bleeding episodes, 18 specified the timing of

occurrence, ${ }^{12} 2830-3639414245-47505253$ nine reported the need for admission due to bleeding, ${ }^{12} 2830313546475053$ and 12 reported data for reintervention. ${ }^{12} 3032343940424647505255$ No study reported transfusion of red blood cells or mortality.

A clear definition of post-tonsillectomy bleeding was presented in two of 29 studies. $^{12}{ }^{42}$ Eight studies stated that bleeding episodes were going to be reported, ${ }^{12} 2831-33353741$ while six clearly questioned their patients about postoperative bleeding or provided instructions in the event of unexpected bleeding. ${ }^{12} 2835374142$ No study described a systematic method to evaluate postoperative bleeding.

\section{Validity assessment}

A low risk of bias was attributed to seven studies $33353640-4250$ (table $2 \Downarrow$ ). Fifteen studies had an adequate sequence generation, ${ }^{12} 303133$ 35--37 40-43 50-52 54 and 15 had an appropriate method of allocation concealment. ${ }^{12} 3033353640-43474850525355$ Six studies were not blinded, 283839454649 and blinding was unclear in another study. ${ }^{34}$ One study was terminated early because of an increased incidence of post-tonsillectomy bleeding in the intervention group. ${ }^{12}$ Fourteen studies ${ }^{12} 31-33363840-4347525355$ reported losses to follow-up that varied from $2.7 \%{ }^{12}$ to $36.1 \%,{ }^{43}$ and losses to follow-up were unclear in four studies. ${ }^{29} 394548$ Eight studies had a follow-up period of $24 \mathrm{~h}$ or less. ${ }^{30} 343744-464951$ Two studies reported performing an intention to treat analysis. ${ }^{12}{ }^{40}$ Five studies did not report all outcomes stated in their methods. $^{32} 45465154$

\section{Post-tonsillectomy bleeding episodes}

The administration of steroids did not increase the incidence of bleeding events after tonsillectomy, based on pooled data from the 29 studies ( $n=2674$, odds ratio $0.96,95 \%$ confidence intervals 0.66 to $1.40, \mathrm{I}^{2}=0 \%$ ), of which eight did not observe any bleeding episodes 2937434448495154 (fig $2 \Downarrow$ ). Sensitivity analyses including trials with low risk of bias, observers blinded to the intervention, larger population, or longer follow-up periods yielded similar results (table $3 \Downarrow$ ). Results were also comparable regardless of the population age, surgical technique, steroid dose, or concomitant administration of non-steroidal anti-inflammatory drugs. When we analysed primary and secondary bleeding events separately, we observed no increase in bleeding incident with the administration of steroids.

\section{Hospital admission}

Seventeen studies reported data for admission ${ }^{12} 2830313546475053$ or reinterventions s $^{36} 394042455255$ that required admission (fig $3 \Downarrow$ ). The incidence of admission due to a bleeding episode did not increase in the steroid group (17 studies, $\mathrm{n}=1722$ patients, odds ratio $1.16,95 \%$ confidence interval 0.68 to $2.00, \mathrm{I}^{2}=19 \%$ ). All sensitivity analyses accorded with this finding (data not shown).

\section{Reintervention for a bleeding episode}

The incidence of operative reintervention for bleeding episodes was significantly increased in the steroid group (12 studies, $\mathrm{n}=1178$; odds ratio $2.27,95 \%$ confidence interval 1.03 to 4.99 , $\mathrm{I}^{2}=0 \%$; fig $4 \Downarrow$ ). The average incidence of reintervention due to bleeding in patients receiving steroids was $3.0 \%$ versus $1.5 \%$ in controls. Sensitivity analyses were performed to evaluate the incidence of reintervention for bleeding episodes among different subgroups (table $4 \Downarrow$ ). We observed a significant increase of reinterventions in children (eight studies $^{12} 30323439464755 ; 3.43,1.29$ to $9.13, \mathrm{I}^{2}=0 \%$ ) but not in adults (four ${ }^{40} 425052 ; 1.07,0.29$ to $4.03, \mathrm{I}^{2}=0 \%$ ). A dose effect was not observed. We found an increased incidence of reinterventions among patients receiving non-steroidal anti-inflammatory drugs (three ${ }^{12} 3952 ; 4.10,0.99$ to $16.97, \mathrm{I}^{2}=0 \%$ ). No significant association was seen among double blinded studies (nine $123032404247505255 ; 2.22,0.95$ to $5.18, \mathrm{I}^{2}=0 \%$ ) and those with longer follow-up periods (nine 3239404247505255 ; $2.16,0.92$ to $5.06, \mathrm{I}^{2}=0 \%$ ). In each case, the incidence of reinterventions for bleeding episodes was increased in the steroid 
group compared with the control group without reaching significance $(\mathrm{P}=0.07$ for double blinding, $\mathrm{P}=0.08$ for longer follow-up periods), although the results suggested a strong trend. Studies with low risk of bias showed no clear association between steroids use and the incidence of operative reintervention (three studies ${ }^{40}{ }^{42} ; 0.91,0.22$ to $3.68, \mathrm{I}^{2}=0 \%$ ).

\section{Allogenic transfusion and mortality}

None of the included studies reported transfusion of red blood cells or mortality.

\section{Publication bias and quality of evidence}

We evaluated the presence of potential publication bias using a funnel plot of intervention effect estimates versus the standard error for studies presenting data for bleeding episodes. Visual inspection of the funnel plot did not reveal evidence of publication bias (web figure). According to the GRADE methodology, the quality of the evidence for bleeding and admission outcomes after tonsillectomy was low; however, the association between post-tonsillectomy reintervention and systemic steroids was considered to be of high quality (table $5 \Downarrow)$.

\section{Discussion}

In this systematic review, we did not observe an increased incidence of postoperative bleeding events after perioperative administration of systemic steroids in patients undergoing tonsillectomy. However, we did observe a significant increase in the incidence of operative reinterventions needed to manage clinically significant bleeding episodes in patients who received systemic steroids. The quality of the evidence according to the GRADE approach was high for this specific outcome. This raised incidence of reinterventions was significantly increased in children.

\section{Strengths and limitations if the study}

An important limitation of our study concerned the data available within included publications. None of the included studies was designed to evaluate adverse complications of steroids use after tonsillectomy, and no study systematically screened for bleeding events after tonsillectomy. Therefore, the incidence of this complication could have been systematically underestimated. Moreover, only two studies presented a clear definition of post-tonsillectomy bleeding. Bleeding episodes of varying severity may not have received equal consideration across all studies, which could lead to an underestimation of overall bleeding episodes. This could explain why we did not observe a significant association between steroids use and bleeding events, while we did observe an association with reintervention for bleeding events.

On the other hand, the inclusion in meta-analyses of studies reporting no bleeding event in either group using a continuity correction could have underestimated the association. The majority of included studies were of limited methodological quality, and many studies had substantial numbers of patients who were lost to follow-up. These factors provide further concern that bleeding episodes may have been missed. A significant proportion of studies had a very limited follow-up period precluding the evaluation of the incidence of secondary bleeding episodes. Since bleeding episodes are relatively rare events, unreported episodes could greatly affect the study results.

Despite of known limitations, our systematic review had important strengths. Firstly, the extensive search strategy using different databases, including the grey literature and conference proceedings, allowed us to retrieve a comprehensive list of the studies performed on the topic. Importantly, the decision to evaluate the incidence of reinterventions for bleeding episodes, as opposed to only bleeding episodes, allowed us to summarise the effect of clinically significant bleeding events with greater fidelity. We believe that operative reintervention for bleeding episodes represents a more reliable and clinically meaningful endpoint than bleeding episodes. Severe enough bleeding events to require operative reintervention are less likely to have been overlooked and may therefore represent the optimal clinical outcome to understand the impact of systemic steroids in tonsillectomy.

\section{Comparison with other studies}

Overall, the mean incidence of post-tonsillectomy bleeding events observed in our systematic review was $4.4 \%$, which is consistent with the current literature. ${ }^{56-60}$ Our results on postoperative bleeding are in accordance with a recent systematic review. ${ }^{15}$ However, this previous meta-analysis identified half the number of studies as compared with our study, and did not evaluate other clinically significant outcomes such as operative reinterventions for bleeding and hospital admission. The increased incidence of reintervention observed in a recent landmark study by Czarnetzki and colleagues ${ }^{12}$ was also seen in our pooled analysis. But our systematic review did not confirm the higher incidence of bleeding episodes associated with perioperative steroids use in tonsillectomy procedures, as observed in this trial.

The increased incidence of reinterventions associated with steroids occurred in the absence of increased bleeding events, and thus probably represents an increased severity of bleeding when steroids are administered. Although no study specified indications to undergo a reintervention in the event of bleeding, this procedure usually suggests that the bleeding was significant enough to require an emergency procedure. Bleeding events requiring reintervention are more likely to be noticed and reported in a publication as opposed to minor events. Therefore, reinterventions to manage bleeding events may be a more objective and reliable outcome to assess clinically significant bleeding events after tonsillectomy.

\section{Conclusions and policy implications}

We did not observe an increased incidence of postoperative bleeding events following administration of systemic steroids during tonsillectomy. We did, however, observe a significant increase in the incidence of operative reintervention associated with the use of steroids, which may be related to an increased severity of a given bleeding episode. Considering the potential for harm and the availability of other drugs to prevent postoperative nausea and vomiting, we recommend that steroids should be used with caution; risks and benefits must be weighted; and steroids should not be used routinely for such purposes, especially in children. Further studies should be designed to answer concerns about the safety of the perioperative use of steroids in tonsillectomy procedures.

We thank Lucie Côté from the Library of the Centre Hospitalier Affilié Universitaire de Québec, Enfant-Jésus Hospital, for her help with the retrieval of study publications.

Contributors: JP, AFT, RZ, FL, LM, and DAF contributed to the conception and design of the study. JP and LV determined eligibility of search results and extracted data from included studies. JP, AB, and AFT performed and reviewed the analyses, and drafted the manuscript. 


\section{What is already known on this topic}

Tonsillectomy is one of the most commonly performed ear, nose, and throat surgeries worldwide, but has a high underlying risk of postoperative nausea and vomiting

Systemic use of steroids to reduce postoperative nausea and vomiting is increasing, and recommended in addition to the use of $5-\mathrm{HT}_{3}$ antagonists in recent guidelines

A recent study has linked such use of steroids with an increased incidence of postoperative bleeding after tonsillectomy

\section{What this study adds}

Overall, the risk of postoperative bleeding did not increase after perioperative administration of systemic steroids in patients undergoing tonsillectomy

However, the incidence of reinterventions for bleeding episodes did increase overall with steroids, and especially among children, which could represent a greater severity of bleeding associated with use of steroids

Systemic steroids should be used with caution; risks and benefits must be weighted, and steroids should not be used routinely to prevent postoperative nausea and vomiting after tonsillectomy, especially in children

All authors participated in the interpretation of the data and the critical review of the manuscript, and approved the version to be published. $\mathrm{AFT}$ is the guarantor.

Funding: This study was funded by personal funds. AFT and FL are recipients of a research career award from the Fonds de Recherche Québec-Santé. AFT and FL are supported by the Traumatology Research Consortium of the Fonds de Recherche Québec-Santé. LM and DAF are recipients of New Investigator Awards from the Canadian Institutes for Health Research. RZ is a recipient of a randomised controlled trials mentorship award from the Canadian Institutes for Health Research.

Competing interests: All authors have completed the Unified Competing Interest form at www.icmje.org/coi_disclosure.pdf (available on request from the corresponding author) and declare: no support from any organisation for the submitted work; no financial relationships with any organisations that might have an interest in the submitted work in the previous three years; no other relationships or activities that could appear to have influenced the submitted work.

Ethical approval: This study did not require ethical approval.

Data sharing: No additional data available.

1 Bolton CM, Myles PS, Nolan T, Sterne JA. Prophylaxis of postoperative vomiting in children undergoing tonsillectomy: a systematic review and meta-analysis. $\mathrm{Br} J$ Anaesth 2006.97.593-604.

2 Steward DL, Grisel J, Meinzen-Derr J. Steroids for improving recovery following tonsillectomy in children. Cochrane Database Syst Rev 2011:CD003997.

3 Randall DA, Hoffer ME. Complications of tonsillectomy and adenoidectomy. Otolaryngol Head Neck Surg 1998:118:61-8.

4 Johnson LB, Elluru RG, Myer CM 3rd. Complications of adenotonsillectomy. Laryngoscope 2002;112:35-6.

5 Litman RS, Wu CL, Catanzaro FA. Ondansetron decreases emesis after tonsillectomy in children. Anesth Analg 1994;78:478-81.

6 Furst SR, Rodarte A. Prophylactic antiemetic treatment with ondansetron in children undergoing tonsillectomy. Anesthesiology 1994;81:799-803.

7 Ferrari LR, Donlon JV. Metoclopramide reduces the incidence of vomiting after tonsillectomy in children. Anesth Analg 1992:75:351-4.

8 Apfel CC, Korttila K, Abdalla M, Kerger H, Turan A, Vedder I, et al. A factorial trial of six interventions for the prevention of postoperative nausea and vomiting. $N$ Engl J Med 2004;350:2441-51.

9 Baugh RF, Archer SM, Mitchell RB, Rosenfeld RM, Amin R, Burns JJ, et al. Clinical Practice Guideline. Otolaryngol Head Neck Surg 2011;144:S1-30.

10 Gan TJ, Meyer TA, Apfel CC, Chung F, Davis PJ, Habib AS, et al. Society for Ambulatory Anesthesia guidelines for the management of postoperative nausea and vomiting. Anesth Analg 2007;105:1615-28.

11 Goldman AC, Govindaraj S, Rosenfeld RM. A meta-analysis of dexamethasone use with tonsillectomy. Otolaryngol Head Neck Surg 2000;123:682-6.

12 Czarnetzki C, Elia N, Lysakowski C, Dumont L, Landis BN, Giger R, et al. Dexamethasone and risk of nausea and vomiting and postoperative bleeding after tonsillectomy in children: a randomized trial. JAMA 2008;300:2621-30.

13 Collison PJ, Mettler B. Factors associated with post-tonsillectomy hemorrhage. Ear Nose Throat J 2000;79:640-2.

14 Macassey EA, Baguley C, Dawes P, Gray A. 15-year audit of post-tonsillectomy haemorrhage at Dunedin Hospital. ANZ J Surg 2007;77:579-82.

15 Geva A, Brigger MT. Dexamethasone and Tonsillectomy Bleeding. Otolaryngol Head Neck Surg 2011;144:838-43.

16 Higgins JPT, Green S, eds. Cochrane handbook for systematic reviews of interventions, version 5.1.0. Cochrane Collaboration, 2011. www.cochrane-handbook.org

17 Wong SS, Wilczynski NL, Haynes RB. Developing optimal search strategies for detecting clinically sound treatment studies in EMBASE. J Med Libr Assoc 2006:94:41-7.

18 Yusuf S PR, Lewis J, Collins R, Sleight P Beta blockade during and after myocardial infarction: an overview of the randomized trials. Prog Cardiovasc Dis 1985;27:335-71.

19 Higgins JP, Thompson SG, Deeks JJ, Altman DG. Measuring inconsistency in meta-analyses. BMJ 2003;327:557-60
20 Ioannidis JP, Trikalinos TA. The appropriateness of asymmetry tests for publication bias in meta-analyses: a large survey. CMAJ 2007;176:1091-6.

21 Atkins D, Best D, Briss PA, Eccles M, Falck-Ytter Y, Flottorp S, et al. Grading quality of evidence and strength of recommendations. BMJ 2004;328:1490.

22 Fujii $\mathrm{Y}$, Tanaka H, Toyooka H. Granisetron and dexamethasone provide more improved prevention of postoperative emesis than granisetron alone in children. Can $J$ Anaesth 1996:43:1229-32.

23 Gunter JB, McAuliffe JJ, Beckman EC, Wittkugel EP, Spaeth JP, Varughese AM. A factoria study of ondansetron, metoclopramide, and dexamethasone for emesis prophylaxis after adenotonsillectomy in children. Paediatr Anaesth 2006;16:1153-65.

24 Liechti M, Feurer R, Gross D, Schmitz A, Stutz K, Gerber A, et al. Prevention of postoperative nausea and vomiting in children following adenotonsillectomy, using tropisetron with or without low-dose dexamethasone. J Anesth 2007;21:311-6.

25 McAuliffe JJ, Gunter JB, Beckman EC. Dose-response relationship of dexamethasone and recovery after tonsillectomy in children [abstract 1228]. American Society of Anesthesiologists Annual Meeting; 2001 October. New Orleans, Anesthesiology, 2001.

26 McAuliffe JJ, Gunter JB, Beckman EC. A factorial study of ondansetron, metoclopramide, and dexamethasone for the prevention of emesis after tonsillectomy in children: model development [abstract 1225]. American Society of Anesthesiologists Annual Meeting; 2001 October. New Orleans, Anesthesiology, 2001.

27 Inci N, Basut O, Kasapoglu F, Coskun H. Management of pain after tonsillectomy: a prospective, randomized clinical study. Kulak Burun Bogaz Ihtis Derg 2009;19:1-8.

28 Alajmi MA, Al Noumas HS, Al-Abdulhadi KA, Kavitha G. Steroids for reducing post-tonsillectomy morbidity. Kuwait Med J 2008;40:211-5.

29 Ammar G, Wang Z. Effect of dexamethasone on post tonsillectomy pain. Lin Chung Er Bi Yan Hou Tou Jing Wai Ke Za Zhi 2009;23:936-8.

30 April MM, Callan ND, Nowak DM, Hausdorff MA. The effect of intravenous dexamethasone in pediatric adenotonsillectomy. Arch Otolaryngol Head Neck Surg 1996;122:117-20.

31 Carr MM, Williams JG, Carmichael L, Nasser JG. Effect of steroids on posttonsillectomy pain in adults. Arch Otolaryngol Head Neck Surg 1999:125:1361-4.

32 Catlin $\mathrm{FI}$, Grimes WJ. The effect of steroid therapy on recovery from tonsillectomy in children. Arch Otolaryngol Head Neck Surg 1991;117:649-52.

33 Giannoni C, White S, Enneking FK. Does dexamethasone with preemptive analgesia improve pediatric tonsillectomy pain? Otolaryngol Head Neck Surg 2002;126:307-15.

34 Güne $Y$, Ünlügenç H, Gündüz M, Tuncer Ü, Akman H. [Comparison of the effects of ondansetron, dexamethasone and droperidol on the nausea and vomiting after tonsillectomy in children]. Çukurova Üniv Tp Fak Derg 2002;27:13-9.

35 Hanasono MM, Lalakea ML, Mikulec AA, Shepard KG, Wellis V, Messner AH. Perioperative steroids in tonsillectomy using electrocautery and sharp dissection techniques. Arch Otolaryngol Head Neck Surg 2004;130:917-21.

36 Holt R, Rask P, Coulthard KP, Sinclair M, Roberts G, Van Der Walt J, et al. Tropisetron plus dexamethasone is more effective than tropisetron alone for the prevention of postoperative nausea and vomiting in children undergoing tonsillectomy. Paediatr Anaesth 2000;10:181-8.

37 Kaan MN, Odabasi O, Gezer E, Daldal A. The effect of preoperative dexamethasone on early oral intake, vomiting and pain after tonsillectomy. Int J Pediatr Otorhinolaryngol 2006;70:73-9

38 Kaufmann M, Deutsch E, Hamouri $\mathrm{H}$. The effect of steroid therapy on post adenotonsillectomy recovery. Harefuah 2006:145:577-80.

$39 \mathrm{Kim} \mathrm{M}$, Lee J, Lee S, Baik S, Chang B. The Effect of Dexamethasone in Tonsillectomy. Korean J Otolaryngol Head Neck Surg 1998;41:783-7.

40 Lachance M, Lacroix $\mathrm{Y}$, Audet N, Savard P, Thuot F. The use of dexamethasone to reduce pain after tonsillectomy in adults: a double-blind prospective randomized trial. Laryngoscope 2008:118:232-6.

41 Malde A, Sonawane V, Jagtap S. Effect of dexamethasone on post tonsillectomy morbidities. Indian J Anaesth 2005;49:202-7.

42 Mathiesen O, Jorgensen DG, Hilsted KL, Trolle W, Stjernholm P, Christiansen H, et al. Pregabalin and dexamethasone improves post-operative pain treatment after tonsillectomy. Acta Anaesthesiol Scand 2011;55:297-305.

43 McKean S, Kochilas X, Kelleher R, Dockery M. Use of intravenous steroids at induction of anaesthesia for adult tonsillectomy to reduce post-operative nausea and vomiting and pain: a double-blind randomized controlled trial. Clin Otolaryngol 2006;31:36-40.

44 Mohamed SK, Ibraheem AS, Abdelraheem MG. Preoperative intravenous dexamethasone combined with glossopharyngeal nerve block: role in pediatric postoperative analgesia following tonsillectomy. Eur Arch Otorhinolaryngol 2009;266:1815-9.

45 Mohammad L, Ahmad R, Latoo M, Qazl S, Wanl A. Post-tonsilelectomy morbidity-do steroids help. Indian J Otolaryngol Head Neck Surg 2006;58:141-3.

46 Nawasreh O, Fraihat A, Maaita J. The effect of preoperative intravenous dexamethasone in pediatric adenotonsillectomy. J Bahrain Med Soc 2000;12:130-3.

47 Ohlms LA, Wilder RT, Weston B. Use of intraoperative corticosteroids in pediatric tonsillectomy. Arch Otolaryngol Head Neck Surg 1995;121:737-42. 
48 Palme CE, Tomasevic P, Pohl DV. Evaluating the effects of oral prednisolone on recovery after tonsillectomy: a prospective, double-blind, randomized trial. Laryngoscope 2000;110:2000-4.

49 Rabbani MZ, Khan MNA, Qureshi R, Zubair M, Bin Pervez M. Does the added benefit of Ondansetron over Dexamethasone, to control post-operative nausea and vomiting, justify the added cost in patients undergoing tonsillectomy and adenotonsillectomy? J Pak Med Assoc 2010;60:559-61.

50 Rujirojindakul P, Atchariyasathian V, Uakritdathikran T, Boonyata N, Boonthida Saefung B. Effect of dexamethasone on postoperative pain after adult tonsillectomy. Thai $J$ Anesthesiol 2008;34:1-8

51 Samarkandi AH, Shaikh MA, Ahmad RA, Alammar AY. Use of dexamethasone to reduce postoperative vomiting and pain after pediatric tonsillectomy procedures. Saudi Med J 2004;25:1636-9.

52 Stewart R, Bill R, Ullah R, McConaghy P, Hall SJ. Dexamethasone reduces pain after tonsillectomy in adults. Clin Otolaryngol Allied Sci 2002;27:321-6.

53 Tom LWC, Templeton JJ, Thompson ME, Marsh RR. Dexamethasone in adenotonsillectomy. Int J Pediatr Otorhinolaryngol 1996;37:115-20.

54 Trujillo M, Ramírez J, Fuentes S. Efecto de la administración de dexametasona intravenosa en pacientes pediátricos post operados de amigdalectomía com o sin adenoidectomía. An ORL Méx 2005;50:61-4.

55 Volk MS, Martin P, Brodsky L, Stanievich JF, Ballou M. The effects of preoperative steroids on tonsillectomy patients. Otolaryngol Head Neck Surg 1993;109:726-30

56 O'Leary S, Vorrath J. Postoperative bleeding after diathermy and dissection tonsillectomy. Laryngoscope 2005;115:591-4.
57 Lee M, Montague M, Hussain S. Post-tonsillectomy hemorrhage: cold versus hot dissection. Otolaryngol Head Neck Surg 2004;131:833-6.

58 British Association of Otorhinolaryngologists-Head and Neck Surgeons Comparative Audit Group and the Clinical Effectiveness Unit of the Royal College of Surgeons of England. National prospective tonsillectomy audit. Royal College of Surgeons of England , 2005.

59 Raut V, Bhat N, Kinsella J, Toner J, Sinnathuray A, Stevenson M. Bipolar scissors versus cold dissection tonsillectomy: a prospective, randomized, multi-unit study. Laryngoscope 2001;111:2178-82.

60 Windfuhr JP, Chen YS. Incidence of post-tonsillectomy hemorrhage in children and adults: a study of 4,848 patients. Ear Nose Throat $J$ 2002;81:626-8.

\section{Accepted: 25 July 2012}

Cite this as: BMJ 2012;345:e5389

This is an open-access article distributed under the terms of the Creative Commons Attribution Non-commercial License, which permits use, distribution, and reproduction in any medium, provided the original work is properly cited, the use is non commercial and is otherwise in compliance with the license. See: http://creativecommons.org/licenses/bync/2.0/ and http://creativecommons.org/licenses/by-nc/2.0/legalcode. 


\section{Tables}

\section{Table 1| Characteristics of included studies in meta-analysis}

\begin{tabular}{|c|c|c|c|c|c|c|c|c|c|c|}
\hline \multirow[b]{2}{*}{$\begin{array}{l}\text { Study } \\
\text { (reference) }\end{array}$} & \multicolumn{2}{|c|}{ No of participants } & \multirow{2}{*}{$\begin{array}{c}\text { Age } \\
\text { inclusion } \\
\text { criteria } \\
\text { (years) }\end{array}$} & \multirow[b]{2}{*}{ Procedure } & \multirow[b]{2}{*}{$\begin{array}{l}\text { Dissection } \\
\text { technique }\end{array}$} & \multicolumn{2}{|c|}{ Drug regimen } & \multirow[b]{2}{*}{$\begin{array}{l}\text { NSAID } \\
\text { use }\end{array}$} & \multirow{2}{*}{$\begin{array}{l}\text { Duration } \\
\text { of } \\
\text { follow-up }\end{array}$} & \multirow{2}{*}{$\begin{array}{l}\text { Bleeding } \\
\text { outcome } \\
\text { definition }\end{array}$} \\
\hline & Steroids & Control & & & & Steroids & Control & & & \\
\hline $\begin{array}{l}\text { Catlin et al. } \\
(1991)^{32}\end{array}$ & 10 & 15 & 4 to 12 & $\begin{array}{l}\mathrm{T} \text {, or } \mathrm{T} \text { and } \\
\mathrm{A}\end{array}$ & Combined & $\begin{array}{l}\text { Dexamethasone IV, } 8 \\
\mathrm{mg} / \mathrm{m}^{2} \text {, before induction }\end{array}$ & Placebo & No & 3 weeks & NR \\
\hline $\begin{array}{l}\text { Volk et al. } \\
(1993)^{55}\end{array}$ & 25 & 25 & 4 to 12 & $\begin{array}{l}\mathrm{T} \text {, or } \mathrm{T} \text { and } \\
\mathrm{A}\end{array}$ & Combined & $\begin{array}{l}\text { Dexamethasone IV, } 10 \mathrm{mg} \text {, } \\
\text { at induction }\end{array}$ & Placebo & No & $\begin{array}{l}7 \text { to } 10 \\
\text { days }\end{array}$ & NR \\
\hline $\begin{array}{l}\text { Ohlms et al. } \\
(1995)^{47}\end{array}$ & 34 & 35 & 3 to 18 & $\begin{array}{l}\mathrm{T} \text {, or } \mathrm{T} \text { and } \\
\mathrm{A}\end{array}$ & $\begin{array}{l}\text { Cold, } \\
\text { combined }\end{array}$ & $\begin{array}{l}\text { Dexamethasone IV, } 0.5 \\
\mathrm{mg} / \mathrm{kg} \text { ( } \mathrm{max} 12 \mathrm{mg}) \\
\text { immediately before surgery }\end{array}$ & Placebo & No & $\begin{array}{l}3 \text { to } 4 \\
\text { weeks }\end{array}$ & NR \\
\hline $\begin{array}{l}\text { April et al. } \\
(1996)^{30}\end{array}$ & 41 & 39 & 3 to 15 & $\mathrm{~T}$ and $\mathrm{A}$ & Hot & $\begin{array}{l}\text { Dexamethasone IV, } 1 \mathrm{mg} / \mathrm{kg} \\
(\mathrm{max} 16 \mathrm{mg}) \text {, after induction }\end{array}$ & Placebo & NR & $24 \mathrm{~h}$ & NR \\
\hline $\begin{array}{l}\text { Tom et al. } \\
(1996)^{53}\end{array}$ & 26 & 32 & 1 to 18 & $\mathrm{~T}$ and $\mathrm{A}$ & Hot & $\begin{array}{l}\text { Dexamethasone IV, } 1 \mathrm{mg} / \mathrm{kg} \\
(\mathrm{max} 10 \mathrm{mg}) \text {, after induction }\end{array}$ & Placebo & No & 10 days & NR \\
\hline $\begin{array}{l}\text { Kim et al. } \\
(1998)^{39}\end{array}$ & 40 & 20 & 3 to 15 & $\begin{array}{l}\mathrm{T} \text {, or } \mathrm{T} \text { and } \\
\mathrm{A}\end{array}$ & Combined & $\begin{array}{l}\text { Dexamethasone IV, } 1 \mathrm{mg} / \mathrm{kg} \\
\text { (max } 15 \mathrm{mg} \text { ), after induction } \\
\text { or in the postanaesthetic } \\
\text { care unit }\end{array}$ & $\begin{array}{l}\text { No treatment or } \\
\text { placebo }\end{array}$ & Yes & 3 days & NR \\
\hline $\begin{array}{l}\text { Carr et al. } \\
(1999)^{31}\end{array}$ & 15 & 14 & Adults & $\mathrm{T}$ & Hot & $\begin{array}{l}\text { Dexamethasone IV, } 20 \text { mg, } \\
\text { during surgery }\end{array}$ & Placebo & No & 10 days & NR \\
\hline $\begin{array}{l}\text { Holt et al. } \\
(2000)^{36}\end{array}$ & 68 & 60 & 2 to 14 & $\begin{array}{l}\mathrm{T} \text {, or } \mathrm{T} \text { and } \\
\mathrm{A}\end{array}$ & Cold & $\begin{array}{l}\text { Tropisetron and } \\
\text { dexamethasone IV, } 0.5 \\
\mathrm{mg} / \mathrm{kg}(\mathrm{max} 8 \mathrm{mg}) \text {, after } \\
\text { induction }\end{array}$ & $\begin{array}{l}\text { Tropisetron alone, } \\
0.1 \mathrm{mg} / \mathrm{kg}(\max 2 \\
\mathrm{mg})\end{array}$ & NR & 6 days & NR \\
\hline $\begin{array}{l}\text { Nawasreh et } \\
\text { al. }(2000)^{46}\end{array}$ & 62 & 58 & 4 to 14 & $\begin{array}{l}\mathrm{T} \text {, or } \mathrm{T} \text { and } \\
\mathrm{A}\end{array}$ & Hot & $\begin{array}{l}\text { Dexamethasone IV, } 1 \mathrm{mg} / \mathrm{kg} \\
\text { (max } 16 \mathrm{mg}), 1 \mathrm{~h} \text { before } \\
\text { surgery }\end{array}$ & Placebo & NR & $24 \mathrm{~h}$ & NR \\
\hline $\begin{array}{l}\text { Palme et al. } \\
(2000)^{48}\end{array}$ & 25 & 25 & $\geq 5$ & $\begin{array}{l}\mathrm{T} \text {, or } \mathrm{T} \text { and } \\
\mathrm{A}\end{array}$ & $\begin{array}{l}\text { Hot, } \\
\text { combined }\end{array}$ & $\begin{array}{l}\text { Prednisolone given orally, } \\
10 \mathrm{mg} \text { daily (age } 5-11 \text { years) } \\
\text { or } 0.5 \mathrm{mg} / \mathrm{kg} \text { daily (age } \geq 12 \\
\text { years), postoperative day } 1 \\
\text { to } 7\end{array}$ & Placebo & No & 2 weeks & NR \\
\hline $\begin{array}{l}\text { Giannoni et al. } \\
(2002)^{33}\end{array}$ & 25 & 25 & 3 to 15 & $\mathrm{~T}$ & Hot & $\begin{array}{l}\text { Dexamethasone IV, } 1 \mathrm{mg} / \mathrm{kg} \\
\text { (max } 16 \mathrm{mg}) \text {, after induction }\end{array}$ & Placebo & Yes & 10 days & NR \\
\hline $\begin{array}{l}\text { Güne et al. } \\
(2002)^{34}\end{array}$ & 15 & 45 & 3 to 12 & $\mathrm{~T}$ & NR & $\begin{array}{l}\text { Dexamethasone IV, } 0.15 \\
\mathrm{mg} / \mathrm{kg} \text {, after induction }\end{array}$ & $\begin{array}{l}3 \text { groups: placebo, } \\
\text { ondansetron, } 0.15 \\
\mathrm{mg} / \mathrm{kg}, \text { or } \\
\text { droperidol, } 0.075 \\
\mathrm{mg} / \mathrm{kg}\end{array}$ & NR & $6 \mathrm{~h}$ & NR \\
\hline $\begin{array}{l}\text { Stewart et al. } \\
(2002)^{52}\end{array}$ & 132 & 68 & $\geq 16$ & $\mathrm{~T}$ & Hot & $\begin{array}{l}\text { Dexamethasone alone or } \\
\text { dexamethasone and } \\
\text { piroxicam (same dose as } \\
\text { controls); dexamethasone } \\
\mathrm{IV}, 8 \mathrm{mg} \text { at induction, } 2 \mathrm{mg} \\
\text { on the night of surgery, } 2 \mathrm{mg} \\
\text { twice daily for } 4 \text { days, } 2 \mathrm{mg} \\
\text { daily for } 4 \text { days }\end{array}$ & $\begin{array}{l}\text { Piroxicam alone, } \\
\text { given orally: } \\
10 \text { mg given } 2 \mathrm{~h} \\
\text { before surgery, } 10 \\
\text { mg given on the } \\
\text { night of surgery; } \\
10 \text { mg given twice } \\
\text { daily for } 4 \text { days; } \\
10 \text { mg given daily } \\
\text { for } 4 \text { days }\end{array}$ & Yes & 2 weeks & NR \\
\hline $\begin{array}{l}\text { Hanasono et } \\
\text { al. }(2004)^{35}\end{array}$ & 106 & 113 & $\leq 12$ & $\begin{array}{l}\mathrm{T} \text {, or } \mathrm{T} \text { and } \\
\mathrm{A}\end{array}$ & $\begin{array}{l}\text { Hot, } \\
\text { combined }\end{array}$ & $\begin{array}{l}\text { Dexamethasone IV, } 1 \mathrm{mg} / \mathrm{kg} \\
\text { (max } 50 \mathrm{mg} \text { ), at the start of } \\
\text { surgery }\end{array}$ & Placebo & NR & 3 days & NR \\
\hline $\begin{array}{l}\text { Samarkandi et } \\
\text { al. }(2004)^{51}\end{array}$ & 29 & 31 & 2 to 12 & $\mathrm{~T}$ & Hot & $\begin{array}{l}\text { Dexamethasone IV, } 0.5 \\
\mathrm{mg} / \mathrm{kg} \text {, after induction }\end{array}$ & Placebo & NR & $24 \mathrm{~h}$ & NR \\
\hline $\begin{array}{l}\text { Malde et al. } \\
(2005)^{41}\end{array}$ & 45 & 45 & $>3$ & $\mathrm{~T}$ & Cold & $\begin{array}{l}\text { Dexamethasone IV, } 0.15 \\
\mathrm{mg} / \mathrm{kg} \text {, after induction }\end{array}$ & Placebo & NR & 7 days & NR \\
\hline
\end{tabular}


Table 1 (continued)

\begin{tabular}{|c|c|c|c|c|c|c|c|c|c|c|}
\hline \multirow[b]{2}{*}{$\begin{array}{l}\text { Study } \\
\text { (reference) }\end{array}$} & \multicolumn{2}{|c|}{ No of participants } & \multirow{2}{*}{$\begin{array}{c}\text { Age } \\
\text { inclusion } \\
\text { criteria } \\
\text { (years) }\end{array}$} & \multirow[b]{2}{*}{ Procedure } & \multirow[b]{2}{*}{$\begin{array}{l}\text { Dissection } \\
\text { technique }\end{array}$} & \multicolumn{2}{|c|}{ Drug regimen } & \multirow[b]{2}{*}{$\begin{array}{l}\text { NSAID } \\
\text { use }\end{array}$} & \multirow{2}{*}{$\begin{array}{c}\text { Duration } \\
\text { of } \\
\text { follow-up }\end{array}$} & \multirow{2}{*}{$\begin{array}{l}\text { Bleeding } \\
\text { outcome } \\
\text { definition }\end{array}$} \\
\hline & Steroids & Control & & & & Steroids & Control & & & \\
\hline $\begin{array}{l}\text { Trujillo et al. } \\
(2005)^{54}\end{array}$ & 35 & 34 & 3 to 15 & $\begin{array}{l}\mathrm{T} \text {, or } \mathrm{T} \text { and } \\
\mathrm{A}\end{array}$ & NR & $\begin{array}{l}\text { Dexamethasone IV; } 1 \mathrm{mg} / \mathrm{kg} \\
\text { (max } 8 \mathrm{mg} \text { ); immediately } \\
\text { before surgery, } 8 \mathrm{~h} \text { after } \\
\text { operation, } 16 \mathrm{~h} \text { after } \\
\text { operation }\end{array}$ & Placebo & NR & 6 days & NR \\
\hline
\end{tabular}

\begin{tabular}{|c|c|c|c|c|c|c|c|c|c|c|}
\hline $\begin{array}{l}\text { Kaan et al. } \\
(2006)^{37}\end{array}$ & 32 & 30 & 4 to 12 & $\begin{array}{l}\mathrm{T} \text {, or } \mathrm{T} \text { and } \\
\mathrm{A}\end{array}$ & Cold & $\begin{array}{l}\text { Dexamethasone IV, } 0.5 \\
\mathrm{mg} / \mathrm{kg} \text { (max } 16 \mathrm{mg} \text { ), after } \\
\text { induction }\end{array}$ & Placebo & NR & $8 \mathrm{~h}$ & NR \\
\hline $\begin{array}{l}\text { Kaufmann et } \\
\text { al. }(2006)^{38}\end{array}$ & 101 & 103 & 2 to 16 & $\mathrm{~T}$ and $\mathrm{A}$ & NR & $\begin{array}{l}\text { Dexamethasone IV, } 0.5 \\
\mathrm{mg} / \mathrm{kg} \text { (max } 10 \mathrm{mg} \text { ), during } \\
\text { surgery }\end{array}$ & $\begin{array}{l}\text { No treatment or } \\
\text { placebo }\end{array}$ & NR & 10 days & $\mathrm{NR}$ \\
\hline $\begin{array}{l}\text { McKean et al. } \\
(2006)^{43}\end{array}$ & 37 & 35 & 16 to 70 & $\mathrm{~T}$ & Combined & $\begin{array}{l}\text { Dexamethasone IV, } 10 \mathrm{mg} \text {, } \\
\text { at induction }\end{array}$ & Placebo & Yes & 7 days & $\mathrm{NR}$ \\
\hline $\begin{array}{l}\text { Mohammad et } \\
\text { al. }(2006)^{45}\end{array}$ & 25 & 25 & 3 to 18 & $\begin{array}{l}\mathrm{T} \text {, or } \mathrm{T} \text { and } \\
\mathrm{A}\end{array}$ & $\begin{array}{l}\text { Cold, } \\
\text { combined }\end{array}$ & $\begin{array}{l}\text { Dexamethasone IV, } 1 \mathrm{mg} / \mathrm{kg} \\
\text { (max } 12 \mathrm{mg} \text { ), during surgery }\end{array}$ & $\begin{array}{l}\text { Unclear } \\
\text { (placebo or no } \\
\text { drug) }\end{array}$ & $\begin{array}{l}\text { Yes } \\
\text { (steroid } \\
\text { group } \\
20 \% \text {, } \\
\text { controls } \\
52 \% \text { ) }\end{array}$ & $24 \mathrm{~h}$ & NR \\
\hline $\begin{array}{l}\text { Alajmi et al. } \\
(2008)^{28}\end{array}$ & 42 & 38 & 5 to 18 & $\begin{array}{l}\mathrm{T} \text {, or } \mathrm{T} \text { and } \\
\mathrm{A}\end{array}$ & $\begin{array}{l}\text { Cold, } \\
\text { combined }\end{array}$ & $\begin{array}{l}\text { Dexamethasone IV, } 1 \mathrm{mg} / \mathrm{kg} \\
\text { (max } 16 \mathrm{mg} \text { ), after induction }\end{array}$ & Placebo & $\begin{array}{l}\text { Yes } \\
\text { (steroid } \\
\text { group } \\
14.3 \% \text {, } \\
\text { controls } \\
47.4 \% \text { ) }\end{array}$ & 16 days & $\mathrm{NR}$ \\
\hline $\begin{array}{l}\text { Czarnetzki et } \\
\text { al. }(2008)^{12}\end{array}$ & 161 & 54 & 2 to 17 & $\begin{array}{l}\mathrm{T} \text {, or } \mathrm{T} \text { and } \\
\mathrm{A}\end{array}$ & $\begin{array}{l}\text { Cold, hot, } \\
\text { combined }\end{array}$ & $\begin{array}{l}3 \text { groups: dexamethasone } \\
\mathrm{IV}, 0.05 \mathrm{mg} / \mathrm{kg}, 0.15 \mathrm{mg} / \mathrm{kg} \text {, } \\
0.5 \mathrm{mg} / \mathrm{kg} \text { ( } \mathrm{max} 20 \mathrm{mg}) \text {; after } \\
\text { induction }\end{array}$ & Placebo & $\begin{array}{l}\text { Yes } \\
\text { (steroid } \\
\text { subgroups } \\
38 \%, 43 \% \text {, } \\
\text { and } 38 \% ; \\
\text { controls } \\
65 \% \text { ) }\end{array}$ & 10 days & $\begin{array}{l}\text { History of } \\
\text { bleeding } \\
\text { leading to } \\
\text { readmission, } \\
\text { with or } \\
\text { without } \\
\text { evidence of } \\
\text { bleeding at } \\
\text { examination } \\
\text { or need for } \\
\text { emergency } \\
\text { reoperation }\end{array}$ \\
\hline $\begin{array}{l}\text { Lachance et } \\
\text { al. }(2008)^{40}\end{array}$ & 41 & 61 & 18 to 45 & $\mathrm{~T}$ & $\begin{array}{l}\text { Combined, } 2 \\
\text { cold } \\
\text { dissections } \\
\text { in control } \\
\text { group }\end{array}$ & $\begin{array}{l}\text { Dexamethasone IV ( } 8 \mathrm{mg} \\
\text { during surgery), } \\
\text { dexamethasone given orally } \\
(8 \mathrm{mg} \text { at home on day of } \\
\text { surgery; } 6,4 \text {, and } 2 \text { mg twice } \\
\text { daily on postoperative days } \\
1,2 \text {, and } 3 \text {, respectively) }\end{array}$ & Placebo & No & 7 days & NR \\
\hline $\begin{array}{l}\text { Rujirojindakul } \\
\text { et al. }(2008)^{50}\end{array}$ & 25 & 25 & 15 to 60 & $\mathrm{~T}$ & Hot & $\begin{array}{l}\text { Dexamethasone IV, } 20 \mathrm{mg} \text {, } \\
\text { after induction }\end{array}$ & Placebo & No & 7 days & NR \\
\hline $\begin{array}{l}\text { Ammar et al. } \\
(2009)^{29}\end{array}$ & 30 & 30 & $\begin{array}{l}\text { Adults and } \\
\text { children }\end{array}$ & $\begin{array}{l}\mathrm{T} \text {, or } \mathrm{T} \text { and } \\
\mathrm{A}\end{array}$ & Cold & $\begin{array}{l}\text { Dexamethasone IV, } 5 \mathrm{mg} \text { to } \\
\text { children, } 10 \mathrm{mg} \text { to adults, for } \\
4 \text { days after surgery }\end{array}$ & Placebo & Yes & 5 days & NR \\
\hline $\begin{array}{l}\text { Mohamed et } \\
\text { al. }(2009)^{44}\end{array}$ & 100 & 50 & 2 to 12 & $\begin{array}{l}\mathrm{T} \text {, or } \mathrm{T} \text { and } \\
\mathrm{A}\end{array}$ & Hot & $\begin{array}{l}2 \text { groups: dexamethasone } \\
\text { alone or dexamethasone } \\
\text { and glossopharyngeal nerve } \\
\text { block (same dose as } \\
\text { controls); dexamethasone } \\
\mathrm{IV}, 0.15 \mathrm{mg} / \mathrm{kg} \text { (max } 8 \mathrm{mg} \text { ), } \\
\text { before surgery }\end{array}$ & $\begin{array}{l}\text { Bilateral } \\
\text { glossopharyngeal } \\
\text { nerve block alone } \\
\text { with } 3 \mathrm{~mL} \text { of } 0.5 \% \\
\text { bupivacaine }\end{array}$ & No & $\begin{array}{l}\text { Until } \\
\text { discharge } \\
\text { time (up to } \\
24 \mathrm{~h} \text { ) }\end{array}$ & NR \\
\hline $\begin{array}{l}\text { Rabbani et al. } \\
(2010)^{49}\end{array}$ & 30 & 30 & $\begin{array}{l}\text { Adults and } \\
\text { children }\end{array}$ & $\begin{array}{l}\mathrm{T} \text {, or } \mathrm{T} \text { and } \\
\mathrm{A}\end{array}$ & NR & $\begin{array}{l}\text { Dexamethasone IV, } 0.1 \\
\mathrm{mg} / \mathrm{kg} \text { for age }<12 \text { years or } \\
8 \mathrm{mg} \text { for }>12 \text { years, at } \\
\text { induction }\end{array}$ & $\begin{array}{l}\text { Ondansetron, } 0.1 \\
\mathrm{mg} / \mathrm{kg} \text { for age }<12 \\
\text { years, } 4 \mathrm{mg} \text { for } \\
\text { age }>12 \text { years }\end{array}$ & NR & $24 \mathrm{~h}$ & NR \\
\hline
\end{tabular}


Table 1 (continued)

\begin{tabular}{|c|c|c|c|c|c|c|c|c|c|c|}
\hline \multirow[b]{2}{*}{$\begin{array}{l}\text { Study } \\
\text { (reference) }\end{array}$} & \multicolumn{2}{|c|}{ No of participants } & \multirow{2}{*}{$\begin{array}{c}\text { Age } \\
\text { inclusion } \\
\text { criteria } \\
\text { (years) }\end{array}$} & \multirow[b]{2}{*}{ Procedure } & \multirow[b]{2}{*}{$\begin{array}{l}\text { Dissection } \\
\text { technique }\end{array}$} & \multicolumn{2}{|c|}{ Drug regimen } & \multirow[b]{2}{*}{$\begin{array}{l}\text { NSAID } \\
\text { use }\end{array}$} & \multirow{2}{*}{$\begin{array}{l}\text { Duration } \\
\text { of } \\
\text { follow-up }\end{array}$} & \multirow{2}{*}{$\begin{array}{l}\text { Bleeding } \\
\text { outcome } \\
\text { definition }\end{array}$} \\
\hline & Steroids & Control & & & & Steroids & Control & & & \\
\hline $\begin{array}{l}\text { Mathiesen et } \\
\text { al. }(2011)^{42}\end{array}$ & 48 & 99 & 18 to 50 & $\mathrm{~T}$ & Combined & $\begin{array}{l}\text { Dexamethasone IV, } 8 \mathrm{mg} \text {, } \\
\text { with paracetamol and } \\
\text { pregabalin (same dose as } \\
\text { controls) before induction }\end{array}$ & $\begin{array}{l}2 \text { groups: } \\
\text { paracetamol } \\
\text { alone, } 1000 \mathrm{mg} \text {, } \\
\text { or paracetamol } \\
\text { and pregabalin, } \\
300 \mathrm{mg}\end{array}$ & No & 2 weeks & $\begin{array}{l}\text { Bleeding } \\
\text { episodes } \\
\text { requiring } \\
\text { reoperation }\end{array}$ \\
\hline
\end{tabular}

$\mathrm{A}=$ adenoidectomy; cold=dissection with cold steel instruments, haemostasis with gauze compression, or ligatures; combined=cold dissection with use of electrocautery for haemostasis; hot=dissection and haemostasis with electric device; IV=intravenous; max=maximum; NR=not reported; NSAID=non-steroidal anti-inflammatory drug; T=tonsillectomy. 


\begin{tabular}{|c|c|c|c|c|c|c|c|c|}
\hline Study (reference) & $\begin{array}{l}\text { Sequence } \\
\text { generation }\end{array}$ & $\begin{array}{l}\text { Allocation } \\
\text { concealment }\end{array}$ & Blinding & $\begin{array}{l}\text { Incomplete } \\
\text { outcome data }\end{array}$ & $\begin{array}{l}\text { Selective } \\
\text { reporting }\end{array}$ & Other bias & $\begin{array}{l}\text { Follow-up period } \\
\qquad(>24 \mathrm{~h})\end{array}$ & Summary \\
\hline Catlin et al. $(1991)^{32}$ & Unclear & Unclear & Low & High & Unclear & Unclear & Low & Unclear \\
\hline Volk et al. $(1993)^{55}$ & Unclear & Low & Low & High & Low & High & Low & Unclear \\
\hline Ohlms et al. $(1995)^{47}$ & Unclear & Low & Low & High & Low & Low & Low & Unclear \\
\hline April et al. $(1996)^{30}$ & Low & Low & Low & Low & Low & Low & High & High \\
\hline Tom et al. $(1996)^{53}$ & Unclear & Low & Low & High & Low & Unclear & Low & Unclear \\
\hline Kim et al. $(1998)^{39}$ & Unclear & High & High & Unclear & Low & High & Low & High \\
\hline Carr et al. $(1999)^{31}$ & Low & Unclear & Low & High & Low & Low & Low & Unclear \\
\hline Holt et al. $(2000)^{36}$ & Low & Low & Low & Low & Low & Low & Low & Low \\
\hline Nawasreh et al. $(2000)^{46}$ & Unclear & High & High & Low & High & Unclear & High & High \\
\hline Palme et al. $(2000)^{48}$ & Unclear & Low & Low & Unclear & Low & Unclear & Low & Unclear \\
\hline Giannoni et al. (2002) ${ }^{33}$ & Low & Low & Low & Low & Low & Low & Low & Low \\
\hline Güne et al. $(2002)^{34}$ & Unclear & High & Unclear & Low & Low & Unclear & High & High \\
\hline Stewart et al. $(2002)^{52}$ & Low & Low & Low & High & Low & Low & Low & Unclear \\
\hline Hanasono et al. (2004) ${ }^{35}$ & Low & Low & Low & Low & Low & Low & Low & Low \\
\hline Samarkandi et al. $(2004)^{51}$ & Low & Unclear & Low & Low & Unclear & Low & High & High \\
\hline Malde et al. $(2005)^{41}$ & Low & Low & Low & Low & Low & Low & Low & Low \\
\hline Trujillo et al. $(2005)^{54}$ & Low & Unclear & Low & Low & Unclear & Low & Low & Unclear \\
\hline Kaan et al. $(2006)^{37}$ & Low & Unclear & Low & Low & Low & Low & High & High \\
\hline Kaufmann et al. (2006) ${ }^{38}$ & Unclear & High & High & High & Low & High & Low & High \\
\hline McKean et al. $(2006)^{43}$ & Low & Low & Low & High & Low & Low & Low & Unclear \\
\hline Mohammad et al. $(2006)^{45}$ & Unclear & Unclear & High & Unclear & Unclear & High & Unclear & High \\
\hline Alajmi et al. $(2008)^{28}$ & High & High & High & Low & Low & High & Low & High \\
\hline Czarnetzki et al. $(2008)^{12}$ & Low & Low & Low & Low & Low & High & Low & Unclear \\
\hline Lachance et al. $(2008)^{40}$ & Low & Low & Low & Low & Low & Low & Low & Low \\
\hline Rujirojindakul et al. $(2008)^{50}$ & Low & Low & Low & Low & Low & Low & Low & Low \\
\hline Ammar et al. $(2009)^{29}$ & Unclear & Unclear & Low & Unclear & Low & Low & Low & Unclear \\
\hline Mohamed et al. $(2009)^{44}$ & Unclear & High & Low & Low & Low & Low & High & High \\
\hline Rabbani et al. $(2010)^{49}$ & High & High & High & Low & Unclear & High & High & High \\
\hline Mathiesen et al. $(2011)^{42}$ & Low & Low & Low & Low & Low & Low & Low & Low \\
\hline
\end{tabular}


Table 3| Sensitivity analysis of post-tonsillectomy bleeding outcome

\begin{tabular}{|c|c|c|c|c|}
\hline Subgroups & No of studies & No of participants & Odds ratio $(95 \% \mathrm{Cl})$ & $I^{2}(\%)$ \\
\hline \multicolumn{5}{|l|}{ Methodological quality } \\
\hline Low risk of bias & 7 & 786 & 0.82 (0.38 to 1.74$)$ & 0 \\
\hline High risk of bias & 11 & 986 & 0.71 (0.31 to 1.61 ) & 0 \\
\hline \multicolumn{5}{|l|}{ Blinding } \\
\hline Double blinded & 22 & 2040 & 1.04 (0.68 to 1.56$)$ & 0 \\
\hline No blinding or unclear & 7 & 634 & $0.67(0.27$ to 1.70$)$ & 0 \\
\hline \multicolumn{5}{|l|}{ Sample size } \\
\hline$<100$ patients & 20 & 1189 & $1.15(0.60$ to 2.42$)$ & 0 \\
\hline$\geq 100$ patients & 9 & 1485 & $0.88(0.55$ to 1.40$)$ & 0 \\
\hline \multicolumn{5}{|l|}{ Duration of follow-up } \\
\hline$\leq 24 \mathrm{~h}$ & 8 & 642 & 0.92 (0.30 to 2.82$)$ & 0 \\
\hline$>24 \mathrm{~h}$ & 21 & 2032 & $0.96(0.64$ to 1.44$)$ & 0 \\
\hline \multicolumn{5}{|l|}{ Age group } \\
\hline Children only & 19 & 1809 & $1.24(0.74$ to 2.08$)$ & 0 \\
\hline Adults only & 6 & 605 & $0.73(0.41$ to 1.30$)$ & 0 \\
\hline \multicolumn{5}{|l|}{ Surgical technique } \\
\hline Cold or combine dissection & 13 & 861 & $0.82(0.43$ to 1.56$)$ & 0 \\
\hline Hot dissection & 9 & 592 & $0.76(0.42$ to 1.40$)$ & 0 \\
\hline \multicolumn{5}{|l|}{ Dose regimen of steroid } \\
\hline$\leq 0.5 \mathrm{mg} / \mathrm{kg}$ & 19 & 1784 & $1.05(0.68$ to 1.61$)$ & 0 \\
\hline$>0.5 \mathrm{mg} / \mathrm{kg}$ & 9 & 840 & $0.77(0.34$ to 1.74$)$ & 0 \\
\hline \multicolumn{5}{|l|}{ Coadministration of NSAID } \\
\hline NSAID & 8 & 787 & 0.92 (0.52 to 1.62$)$ & 26 \\
\hline No NSAID & 20 & 1683 & $1.00(0.60$ to 1.65$)$ & 0 \\
\hline \multicolumn{5}{|l|}{ Type of comparator } \\
\hline Placebo & 20 & 1615 & $1.32(0.80$ to 2.20$)$ & 0 \\
\hline Other drugs & 6 & 745 & 0.62 (0.33 to 1.16$)$ & 0 \\
\hline \multicolumn{5}{|l|}{ Moment of bleeding episode } \\
\hline Primary bleedings & 9 & 952 & 0.93 (0.33 to 2.59$)$ & 0 \\
\hline Secondary bleedings & 14 & 1437 & $0.97(0.61$ to 1.56$)$ & 18 \\
\hline
\end{tabular}

Cold=dissection with cold steel instruments, haemostasis with gauze compression, or ligatures; combined=cold dissection with use of electrocautery for haemostasis; hot=dissection and haemostasis with electric device; NSAID=non-steroidal anti-inflammatory drug 
Table 4| Sensitivity analysis of operative reintervention to treat post-tonsillectomy bleeding

\begin{tabular}{|c|c|c|c|c|}
\hline Subgroups & No of studies & No of participants & Odds ratio $(95 \% \mathrm{Cl})$ & $I^{2}(\%)$ \\
\hline \multicolumn{5}{|l|}{ Methodological quality } \\
\hline Low risk of bias & 3 & 299 & 0.91 (0.22 to 3.68$)$ & 0 \\
\hline High risk of bias & 4 & 320 & $3.31(0.51$ to 21.61$)$ & 0 \\
\hline \multicolumn{5}{|l|}{ Blinding } \\
\hline Double blinded & 9 & 938 & 2.22 (0.95 to 5.18$)$ & 0 \\
\hline No blinding or unclear & 3 & 240 & 2.64 (0.31 to 22.41$)$ & 0 \\
\hline \multicolumn{5}{|l|}{ Sample size } \\
\hline$<100$ patients & 7 & 394 & 3.85 (1.13 to 13.17$)$ & 0 \\
\hline$\geq 100$ patients & 5 & 784 & 1.57 (0.56 to 4.38$)$ & 0 \\
\hline \multicolumn{5}{|l|}{ Follow-up } \\
\hline$\leq 24 \mathrm{~h}$ & 3 & 260 & 3.06 (0.37 to 25.07$)$ & 0 \\
\hline$>24 \mathrm{~h}$ & 9 & 918 & 2.16 (0.92 to 5.06$)$ & 0 \\
\hline \multicolumn{5}{|l|}{ Age group } \\
\hline Children only & 8 & 679 & 3.43 (1.29 to 9.13$)$ & 0 \\
\hline Adults only & 4 & 499 & 1.07 (0.29 to 4.03$)$ & 0 \\
\hline \multicolumn{5}{|l|}{ Surgical technique } \\
\hline Cold or combined dissection & 6 & 453 & $1.45(0.50$ to 4.20$)$ & 0 \\
\hline Hot dissection & 4 & 450 & 3.84 (0.53 to 28.00$)$ & 0 \\
\hline \multicolumn{5}{|l|}{ Dosage regimen of steroid } \\
\hline$\leq 0.5 \mathrm{mg} / \mathrm{kg}$ & 8 & 816 & 2.45 (1.04 to 5.76$)$ & 0 \\
\hline$>0.5 \mathrm{mg} / \mathrm{kg}$ & 4 & 362 & $1.52(0.21$ to 11.20$)$ & 0 \\
\hline \multicolumn{5}{|l|}{ Coadministration of NSAID } \\
\hline NSAID & 3 & 475 & 4.10 (0.99 to 16.97$)$ & 0 \\
\hline No NSAID & 9 & 703 & 1.75 (0.68 to 4.50$)$ & 0 \\
\hline
\end{tabular}

Cold=dissection with cold steel instruments, haemostasis with gauze compression, or ligatures; combined=cold dissection with use of electrocautery for haemostasis; hot=dissection and haemostasis with electric device; NSAID=non-steroidal anti-inflammatory drug. 
Table 5 Summary of evidence for key outcomes

\begin{tabular}{|c|c|c|c|c|}
\hline \multirow[t]{2}{*}{ Outcome } & \multirow{2}{*}{$\begin{array}{c}\text { No of } \\
\text { participants/studies }\end{array}$} & \multirow{2}{*}{$\begin{array}{l}\text { Quality of evidence } \\
\text { (GRADE) }\end{array}$} & \multicolumn{2}{|c|}{ Summary } \\
\hline & & & Relative effect, odds ratio $(95 \% \mathrm{Cl})$ & $\begin{array}{c}\text { Study events rates (steroid/control } \\
\text { groups }(\%))\end{array}$ \\
\hline $\begin{array}{l}\text { Post-tonsillectomy bleeding } \\
\text { episodes }\end{array}$ & $2674 / 29$ & Very low & $0.96(0.66$ to 1.40$)$ & $4.6 / 4.2$ \\
\hline Admission & $1722 / 17$ & Very low & $1.16(0.68$ to 2.00$)$ & $4.1 / 3.1$ \\
\hline Reintervention & $1178 / 12$ & High & 2.27 (1.03 to 4.99$)$ & $3.0 / 1.5$ \\
\hline
\end{tabular}




\section{Figures}



Fig 1 Flow diagram of studies 


\begin{tabular}{|c|c|c|c|c|c|c|}
\hline \multirow[b]{2}{*}{ Study } & \multicolumn{2}{|c|}{ Events/total } & \multirow{2}{*}{\multicolumn{2}{|c|}{$\begin{array}{l}\text { Peto odds ratio, } \\
\text { fixed }(95 \% \mathrm{Cl})\end{array}$}} & \multirow[b]{2}{*}{$\begin{array}{l}\text { Weight } \\
\text { (\%) }\end{array}$} & \multirow[b]{2}{*}{$\begin{array}{c}\text { Peto odds ratio, } \\
\text { fixed }(95 \% \mathrm{Cl})\end{array}$} \\
\hline & \multirow{2}{*}{$\begin{array}{c}\text { Steroids } \\
0 / 42\end{array}$} & \multirow{2}{*}{$\begin{array}{l}\text { Control } \\
3 / 38\end{array}$} & & & & \\
\hline Alajmi et al 2008 & & & & & 3.0 & 0.12 (0.01 to 1.14$)$ \\
\hline Ammar et al 2009 & $0 / 30$ & $0 / 30$ & & & 0.0 & $1.00(0.02$ to 50.40$)$ \\
\hline April et al 1996 & $1 / 41$ & $1 / 39$ & & & 2.0 & $0.95(0.06$ to 15.48$)$ \\
\hline Carr et al 1999 & $1 / 17$ & $2 / 17$ & & & 2.9 & $0.49(0.05$ to 5.08$)$ \\
\hline Catlin et al 1991 & $2 / 10$ & $1 / 15$ & & & 2.7 & $3.36(0.30$ to 37.51$)$ \\
\hline Czarnetzki et al 2008 & $20 / 161$ & $2 / 54$ & & & 15.1 & 2.57 (0.93 to 7.09$)$ \\
\hline Giannoni et al 2002 & $1 / 25$ & $1 / 25$ & & & 2.0 & $1.00(0.06$ to 16.45$)$ \\
\hline Güne et al 2002 & $1 / 15$ & $1 / 45$ & & & 1.5 & $3.88(0.15$ to 97.94$)$ \\
\hline Hanasono et al 2004 & $1 / 106$ & $1 / 113$ & & & 2.0 & $1.07(0.07$ to 17.18$)$ \\
\hline Holt et al 2000 & $1 / 68$ & $2 / 60$ & & & 3.0 & $0.45(0.05$ to 4.38$)$ \\
\hline Kaan et al 2006 & $0 / 32$ & $0 / 30$ & & & 0.0 & $0.94(0.02$ to 47.39$)$ \\
\hline Kaufmann et al 2006 & $3 / 101$ & $4 / 103$ & & & 6.9 & $0.76(0.17$ to 3.42$)$ \\
\hline Kim et al 1998 & $1 / 40$ & $0 / 20$ & & & 0.9 & 4.48 (0.07 to 286.49$)$ \\
\hline Lachance et al 2008 & $3 / 41$ & $5 / 61$ & & & 7.2 & 0.89 (0.20 to 3.84) \\
\hline Malde et al 2005 & $0 / 45$ & $1 / 45$ & & & 1.0 & $0.14(0.00$ to 6.82$)$ \\
\hline Mathiesen et al 2011 & $2 / 48$ & $9 / 99$ & & & 9.1 & 0.49 (0.13 to 1.82$)$ \\
\hline Mckean et al 2006 & $0 / 37$ & $0 / 35$ & & & 0.0 & $0.95(0.02$ to 47.78$)$ \\
\hline Mohamed et al 2009 & $0 / 100$ & $0 / 50$ & & & 0.0 & $0.48(0.01$ to 30.28$)$ \\
\hline Mohammad et al 2006 & $5 / 25$ & $1 / 25$ & & & 1.0 & 0.14 (0.00 to 6.82$)$ \\
\hline Nawasreh et al 2000 & $2 / 62$ & $2 / 58$ & & & 3.9 & 0.93 (0.13 to 6.81) \\
\hline Ohlms et al 1995 & $3 / 34$ & $0 / 35$ & & & 2.9 & $8.09(0.81$ to 80.51$)$ \\
\hline Palme et al 2000 & $0 / 25$ & $0 / 25$ & & & 0.0 & $1.00(0.02$ to 50.4$)$ \\
\hline Rabbani et al 2010 & $0 / 30$ & $0 / 30$ & & & 0.0 & $1.00(0.02$ to 50.4$)$ \\
\hline Rujirojindakul 2008 & $3 / 25$ & $0 / 25$ & & & 2.9 & 8.05 (0.80 to 81.12$)$ \\
\hline Samarkandi et al 2004 & 4 $0 / 29$ & $0 / 31$ & & & 0.0 & $1.06(0.02$ to 53.93$)$ \\
\hline Stewart et al 2002 & $17 / 132$ & $13 / 68$ & & & 23.3 & 0.61 (0.27 to 1.39$)$ \\
\hline Tom et al 1996 & $1 / 26$ & $3 / 32$ & & & 3.8 & 0.43 (0.06 to 3.25$)$ \\
\hline Trujillo et al 2005 & $0 / 35$ & $0 / 34$ & & & 0.0 & $0.97(0.02$ to 49.00$)$ \\
\hline Volk et al 1993 & $2 / 25$ & $1 / 25$ & & & 2.9 & $2.00(0.20$ to 20.20$)$ \\
\hline Total $(95 \% \mathrm{Cl})$ & $65 / 1407$ & $53 / 1267$ & & & 100.0 & 0.96 (0.66 to 1.40$)$ \\
\hline Test for heterogeneity: $\chi$ & $\chi^{2}=21.77$ & $d f=28$ & 0.01 & 10 & 100 & \\
\hline $\begin{array}{l}P=0.80, I^{2}=0 \% \\
\text { Test for overall effect: } z=\end{array}$ & $c$ & & $\begin{array}{l}\text { Lower odds } \\
\text { of bleeding } \\
\text { with steroids }\end{array}$ & $\begin{array}{l}\text { Highe } \\
\text { of bl } \\
\text { with s }\end{array}$ & $\begin{array}{l}\text { odds } \\
\text { eding } \\
\text { roids }\end{array}$ & \\
\hline
\end{tabular}

Fig 2 Post-tonsillectomy bleeding. For Peto odds ratio, continuity correction k=0.5 was used when there was no event in both groups 


\begin{tabular}{|c|c|c|c|c|c|c|}
\hline \multirow[b]{2}{*}{ Study } & \multicolumn{2}{|c|}{ Events/total } & \multirow{2}{*}{\multicolumn{2}{|c|}{$\begin{array}{l}\text { Peto odds ratio, } \\
\text { fixed }(95 \% \mathrm{Cl})\end{array}$}} & \multirow[b]{2}{*}{$\begin{array}{l}\text { Weight } \\
\text { (\%) }\end{array}$} & \multirow[b]{2}{*}{$\begin{array}{l}\text { Peto odds ratio, } \\
\text { fixed }(95 \% \mathrm{Cl})\end{array}$} \\
\hline & Steroids & Control & & & & \\
\hline Alajmi et al 2008 & $0 / 42$ & $3 / 38$ & & & 5.6 & $0.12(0.01$ to 1.14$)$ \\
\hline April et al 1996 & $0 / 41$ & $1 / 39$ & & & 1.9 & $0.13(0.00$ to 6.49$)$ \\
\hline Carr et al 1999 & $1 / 17$ & $2 / 17$ & & & 5.4 & 0.49 (0.05 to 5.08$)$ \\
\hline Czarnetzki et al 2008 & 20161 & $2 / 54$ & & & 28.6 & 2.57 (0.93 to 7.09$)$ \\
\hline Güne et al 2002 & $1 / 15$ & $1 / 45$ & & & 2.8 & $3.88(0.15$ to 97.94$)$ \\
\hline Hanasono et al 2004 & $1 / 106$ & $1 / 113$ & & & 3.8 & 1.07 (0.07 to 17.18$)$ \\
\hline Holt et al 2000 & $1 / 68$ & $2 / 60$ & & & 5.6 & $0.45(0.05$ to 4.38$)$ \\
\hline Kim et al 1998 & $1 / 40$ & $0 / 20$ & & & 1.74 & 4.48 (0.07 to 286.49$)$ \\
\hline Lachance et al 2008 & $0 / 41$ & $1 / 61$ & & & 1.8 & $0.19(0.00$ to 10.23$)$ \\
\hline Mathiesen et al 2011 & $2 / 48$ & $5 / 99$ & & & 11.3 & $0.82(0.16$ to 4.14$)$ \\
\hline Mohammad et al 2006 & $6 \quad 0 / 25$ & $1 / 25$ & & & 1.9 & 0.14 (0.00 to 6.82) \\
\hline Nawasreh et al 2000 & $2 / 62$ & $2 / 58$ & & & 7.5 & $0.93(0.13$ to 6.81$)$ \\
\hline Ohlms et al 1995 & $2 / 34$ & $0 / 35$ & & & 3.87 & 7.84 (0.48 to 128.05$)$ \\
\hline Rujirojindakul 2008 & $3 / 25$ & $0 / 25$ & & & 5.5 & $8.05(0.80$ to 81.12$)$ \\
\hline Stewart et al 2002 & $1 / 132$ & $0 / 68$ & & & 1.74 & 4.55 (0.07 to 285.04$)$ \\
\hline Tom et al 1996 & $0 / 26$ & $32 / 32$ & & & 5.5 & 0.15 (0.02 to 1.55$)$ \\
\hline Volk et al 1993 & $2 / 25$ & $1 / 25$ & & & 5.5 & $2.00(0.20$ to 20.20$)$ \\
\hline Total $(95 \% \mathrm{Cl})$ & $37 / 908$ & $25 / 814$ & & & 100.0 & 1.16 (0.68 to 2.00$)$ \\
\hline \multicolumn{3}{|c|}{$\begin{array}{l}\text { Test for heterogeneity: } \chi^{2}=19.84, d f=16 \text {, } \\
P=0.23,\left.\right|^{2}=19 \%\end{array}$} & & 100 & & \\
\hline $\begin{array}{l}P=0.23, I^{2}=19 \% \\
\text { Test for overall effect: } z=\end{array}$ & 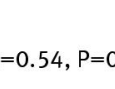 & 0.59 & \multicolumn{2}{|l|}{$\begin{array}{l}\text { Lower odds } \\
\text { of admission } \\
\text { with steroids }\end{array}$} & & \\
\hline
\end{tabular}

Fig 3 Admission for post-tonsillectomy bleeding 